\title{
On the formability of sheet steels
}

\author{
S K PAUL and SANAK MISHRA* \\ R\&D Centre for Iron and Stecl. Steel Authority of India Limited. Ranchi 834002 , India
}

\begin{abstract}
Formability of sheet sted in stamping operation primarily depends on strain hardening exponent $(n)$, average plastic strain ratio $(\vec{r})$ and the maxumum strain the material can undergo before the onset of localized necking. The formability parameters ( $n$ and $\vec{F}$ ) and the forming limil diagrams have been evaluated for a variety of sheet steel products, extensively used for press forming of components of diverse shapes e.g. extra deep drawing quality auto-body sheets, high strength cold rolled sheets. LPG steel for gas cylinders, austenitic and ferritic stainless steels, etc. The effect of sulphide shape control on formability of hot rolled HSLA steel has also been studied. Additionally, the press performance of auto-body sheets and austenitic stainless stecis have heen monitored and evaluated at customer's end for complete information on the formability.
\end{abstract}

Keywords. Formability: strain hardening exponent; average plastic strain ratio; forming limit diagram; low carbon steel: stainless stecl.

\section{Introduction}

Formability is the ability of a material to be formed into a specific shape. Low carbon sheet steels are extensively used in press forming applications. The formability (Blickwede 1968; Mishra and Darmann 1982; Blickwede 1984) of these steels can be described as deep drawability and stretchability. Drawability is the ability of a material to flow easily in the plane of the sheet and resist thinning in the thickness direction. The average plastic strain ratio $(\vec{r})$. as defined by Lankford et al $(1950)$, has been shown to be directly related to the depth of draw. The higher the $\vec{r}$ value. deeper is the cup that can be drawn (W'hiteley et al 1961). On the other hand, stretchability represents the ability of the material to resist localized necking and, thereby, withstand complex non-uniform deformation. It is primarily related to the strain hardening exponent $(n)$. The higner the $n$ value, greater is the ability of the material to distribute strain in the presence of a stress gradient (Keeler and Brazier 1977). In the press forming of a given component. either of the above-mentioned parameters predominates depending upon its shape.

A complex stamping can be formed by any combination of several forming modes such as stretching, deep drawing, flanging, bending etc. However, a successful stamping can be made only if the strain level within the stamping does not exceed the critical strain of the material at the onset of failure (Keeler and Brazier 1977). Thus, the strain level at the onset of failure is an important measure of sheet metal formability. The methodology of representing the critical or acceptabie strain limits during sheet metal stamping was developed by Keeler (1965) and Goodwin (1968). which resulted in the concept of forming limit diagram (FLD). A forming limit diagram represents the limit strains of sheet metal in the principal strain coordinates over all possibie strain ratios in the plane of the sheet (Hecker 1975). It denotes, in practice, the end of useful deformation during sheet forming. Forming limit diagrams have been shown (Pearce 1971; Hiam and Lee 1978; Mellor 1981) to be of considerable practical help in solving sheet stamping problems.

*Author for correspondence 
The use of high-strength low-alloy (HSLA) steel sheet/plate for cold forming application is largely controlled by transverse bendability. During hot rolling, the non-metallic inclusions, which are plastic at elevated temperatures such as manganese sulphide, get highly elongated in the rolling direction (Paul et al 1982a, b). These MnS stringers drastically reduce the bendability (Paul and Mishra 1992), stretchability ( $n$ ) and critical strain (Keeler and Brazier 1977; Paul and Mishra 1992) in the direction transverse to the rolling direction. The deleterious effect of such inclusions on cold formability can be minimized, or even eliminated, by forming high melting point non-deformable sulphides/oxysulphides (Paul et al 1982b; Paul and Mishra 1992) through addition of rare earth metals (REM).

The present paper deals with the formability properties of a variety of sheet steel products used for press forming of components of diverse shapes. Additionally, press performance trials for some of these steels for forming a few critical components have been discussed to provide complete information on the formability characteristics.

\section{Steels investigated}

The steels used in the present investigation were from various press forming sheet steels such as low carbon hot and cold rolled deep drawing steels, stainless steels and high-strength low-alloy steels. The details of these are given here: (i) cold-rolled and annealed extra deep drawing (EDD) quality aluminium-killed steels (Paul et al 1985, 1989) used for forming various components in automobile industries, (ii) high-strength cold-rolled (HSCR) and annealed sheet steels (Paul et al 1993) used for automotive stamping and other engineering applications, (iii) hot-rolled deep drawing quality LPG grade steel (Paul and Mishra 1988) used for forming low pressure liquefiable gas cylinders, (iv) cold-rolled and annealed AISI 304 grade austenitic stainless steels used for household utensils and industrial machinery, (v) cold-rolled and annealed AISI 430 grade ferritic stainless steel used for domestic and medical appliances as well as structural applications, (vi) cold-rolled and annealed low $\mathrm{Ni}$ austenitic stainless steel used for non-cooking utensils and other domestic appliances and (vii) hot-rolled high-strength low-alloy (HSLA) steel (Paul and Mishra 1992) used for structural applications.

Steel samples from the seven above mentioned grades with a wide range of properties were studied in the present work. The chemical compositions of these steels are given in table 1 . The materials for low carbon deep drawing steels included sheets from six EDD heats in the thickness range of 0.80 to $2.0 \mathrm{~mm}$, sheets from three HSCR heats of $1.0 \mathrm{~mm}$ thickness each and sheets from three LPG heats of $3.1 \mathrm{~mm}$ thickness each. The variation in chemistry for each grade of steel was within a very narrow range and is shown in table 1 . For stainless steels, only one sheet sample of $1.0 \mathrm{~mm}$ thickness was used for investigation from each of the three grades shown in table 1.

The high-strength low-alloy steels used in the present study belonged to the same heat and the chemical composition is given in table 1 . However, varying amounts of rare earth metals (REM) at the rate of $0.5 \mathrm{~kg} /$ ton, $1.0 \mathrm{~kg} /$ ton and $1.5 \mathrm{~kg} /$ ton of steel were added in the moulds for sulphide shape control (Paul et al 1982a). All these REM treated ingots along with a untreated one were processed into $5.3 \mathrm{~mm}$ thick sheets and samples were collected for evaluation of formability properties. 
Table 1. Compositions of steels investigated.

\begin{tabular}{|c|c|c|c|c|c|c|c|c|c|c|}
\hline \multirow[b]{2}{*}{ Sl. No. } & \multirow[b]{2}{*}{ Grade } & \multicolumn{7}{|c|}{ Element (wt.\%) } & & \\
\hline & & $\mathrm{C}$ & $\mathrm{Mn}$ & $\mathbf{P}$ & $\mathrm{S}$ & $\mathrm{Si}$ & $\mathrm{Al}$ & $\mathrm{Nb}$ & & \\
\hline \multicolumn{11}{|c|}{ (a) Low carbon deep drawing steels } \\
\hline 1 & EDD & $\begin{array}{l}0.04 / \\
0.06\end{array}$ & $\begin{array}{l}0.25 / \\
0.35\end{array}$ & $\begin{array}{l}0.012 / \\
0.022\end{array}$ & $\begin{array}{l}0.017 / \\
0.023\end{array}$ & $\begin{array}{l}0.02 / \\
0.03\end{array}$ & $\begin{array}{c}0.04 / \\
0 \cdot 07\end{array}$ & - & & \\
\hline 2 & HSCR & $\begin{array}{c}0.06 / \\
0.07\end{array}$ & $\begin{array}{l}0.35 / \\
0.42\end{array}$ & $\begin{array}{l}0.012 \\
0.016\end{array}$ & $\begin{array}{l}0.020 / \\
0.025\end{array}$ & 0.02 & $\begin{array}{l}0-04 / \\
0.07\end{array}$ & $\begin{array}{l}0.03 i \\
0.036\end{array}$ & & \\
\hline 3 & LPG & $\begin{array}{l}0.09 / \\
0.11\end{array}$ & $\begin{array}{l}0.41 / \\
0.45\end{array}$ & $\begin{array}{l}0.018 \\
0.025\end{array}$ & $\begin{array}{l}0.022 / \\
0.025\end{array}$ & $\begin{array}{l}0.04 \\
0.16\end{array}$ & $\begin{array}{l}0.03 \\
0.05\end{array}$ & - & & \\
\hline \multicolumn{11}{|c|}{ Element (wt. \%) } \\
\hline Sl. No. & Grade & $\mathrm{C}$ & $\mathrm{Mn}$ & $\mathrm{P}$ & $\mathrm{S}$ & $\mathrm{Si}$ & $\mathrm{Cr}$ & $\mathrm{Ni}$ & Mo & $\mathrm{Cu}$ \\
\hline \multicolumn{11}{|c|}{ (b) Stainless steels } \\
\hline 4 & AISI 304 & $0 \cdot 04$ & 1.55 & 0019 & 0.003 & 0.57 & $18 \cdot 13$ & $8 \cdot 68$ & $0 \cdot 20$ & - \\
\hline 5 & AISI 430 & 0.04 & $0 \cdot 35$ & $0 \cdot 021$ & 0.005 & 0.26 & $16 \cdot 99$ & $0 \cdot 16$ & 0.02 & -- \\
\hline 6 & $\begin{array}{l}\text { Low } \mathrm{Ni} \\
\text { austenitic }\end{array}$ & 0.04 & $8 \cdot 36$ & 0.08 & $0 \cdot 01$ & 0.47 & $14 \cdot 65$ & $2 \cdot 27$ & - & $1 \cdot 60$ \\
\hline \multicolumn{11}{|c|}{ Element (wt. \%) } \\
\hline Si. No. & Grade & $\mathrm{C}$ & $\mathrm{Mn}$ & $\mathrm{P}$ & $\mathrm{S}$ & $\mathrm{Si}$ & $\mathrm{Al}$ & $\mathrm{Nb}$ & & \\
\hline \multicolumn{11}{|c|}{ (c) High strength low alloy steel } \\
\hline 7 & HSLA & $0 \cdot 14$ & $1 \cdot 38$ & 0.019 & $0 \cdot 014$ & $0 \cdot 14$ & 0.05 & 0.022 & & \\
\hline
\end{tabular}

\section{Experimental}

Tensile specimens of $50 \mathrm{~mm}$ gauge length and $12.5 \mathrm{~mm}$ width were prepared from each steel and were tested at a cross head speed of $5 \mathrm{~mm} \mathrm{~min}^{-1}$ on a static Instron machine (Model 1195). During testing, a $50 \mathrm{~mm}$ extensometer was used before the onset of necking to measure the uniform elongation. True stress $(\sigma)$ and the corresponding true strain $(\varepsilon)$ values were calculated at several points within the region of uniform elongation. The strain hardening coefficient $(n)$ was computed using the Hollomon equation, viz.

$$
\sigma=K \varepsilon^{n}
$$

where $K$ is the strength coefficient. The $n$ values corresponding to tensile axis inclined at $0^{\circ}, 45^{\circ}$ and $90^{\circ}$ to the rolling direction were determined and the $n$ values were calculated from the relation

$$
\vec{n}=\left(n_{0}+n_{90}+2 n_{45}\right) / 4 \text {. }
$$

The average plastic strain ratio ( $r$ ) was measured for the EDD, HSCR and ferritic stainless steels using a Modul- $\bar{r}$ drawability tester. Here, the Young's Modulus $(E)$ was 
determined from the resonant frequency $(f)$ using a standard table, for specimens blanked at $0^{\circ}, 45^{\circ}$ and $90^{\circ}$ to the rolling direction. The average $\bar{E}$ was then calculated from the relation

$$
\bar{E}=\left(E_{0}+E_{90}+2 E_{45}\right) / 4 \text {. }
$$

The $\vec{r}$ values were then obtained from a calibration table between $\bar{E}$ and $\bar{r}$. In a similar manner, the planar anisotropy $(\Delta r)$ was determined from the calibration table between $\Delta r$ and $\Delta E$, where

$$
\Delta E=\left(E_{0}+E_{90}-2 E_{45}\right) / 2
$$

Since the Modul- $\bar{r}$ drawability tester employs the magnetostriction principle for measuring the longitudinal resonant frequency, the specimen to be tested must be a ferromagnetic material. Another limitation of Modul- $\bar{r}$ drawability tester is that it can accommodate thicknesses only between 0.2 to $2.0 \mathrm{~mm}$. Thus, the $\bar{r}$ values of AISI 304 and low nickel austenitic stainless steels (being non-magnetic) as well as HSLA and LPG sheets (being thicker than $2.0 \mathrm{~mm}$ ) could not be measured in the Modul $\bar{r}$ drawability tester. The $\vec{r}$ and $\Delta r$ of these steels were measured following the procedure as described earlier (Paul et al 1992).

The forming limit diagrams (FLDs) were evaluated using a universal sheet and strip metal testing machine (Model 145-60 of M/s Erichsen). The specimens used were of $220 \mathrm{~mm}$ length and varying widths in the range of 25 to $200 \mathrm{~mm}$ (in multiples of $25 \mathrm{~mm}$ ). Due to limitations in the machine, the HSLA and LPG sheet samples were ground to $2.5 \mathrm{~mm}$ and $2.85 \mathrm{~mm}$ from the original sheet thickness of $5.3 \mathrm{~mm}$ and $3.10 \mathrm{~mm}$ respectively. The specimens of all these steels were electro-chemically grid-marked with $5 \mathrm{~mm}$ diameter contacting type circular grids and then punch stretched to failure without load interruption using a $100 \mathrm{~mm}$ diameter hemispherical steel punch. The detailed description of the methodology used for the experimental evaluation of FLD has been reported earlier (Paul et al 1992). The deformation speed was kept constant at $12 \mathrm{~mm} \mathrm{~min}^{-1}$ during stretching. During testing the samples were clamped firmly with serrated dies. The blank holding pressure was optimized to prevent drawing in for each grade of steel and was $160 \mathrm{KN}$ for EDD/ HSCR steels, $200 \mathrm{KN}$ for the stainless steels, $230 \mathrm{KN}$ for LPG steel and $240 \mathrm{KN}$ for HSLA steels. Two blanks were tested for each width without lubrication to obtain more data points.

\section{Results and discussion}

\subsection{Strain hardening exponent (n)}

The strain hardening exponent measures the ability of the material to distribute strain uniformly, and sheet steel with a high $\bar{n}$ value exhibits good stretching behaviour. The $\bar{n}$ values of various steels investigated are shown in table 2 .

The $\bar{n}$ values of EDD steels were found in the range of 0.22 to 0.25 . It is well known that $n$ value is strongly dependent on the grain size and increases with ferrite grains (Morrison 1966). However, grain sizes larger than ASTM 6, i.e. $44 \mu \mathrm{m}$, give rise to orange-peel effect, which adversely affects the surface quality and is not desirable. 
Higher substitutional solutes, carbide precipitates and sulphide stringers also affect $n$ adversely (Morrison 1966; Blickwede 1968). The grain sizes of all the EDD steels investigated in the present study were between ASTM 7 to 8 which is common for this type of steel (Paul et al 1985, 1989). The $\bar{n}$ values of other boc steels such as HSCR, LPG, ferritic stainless and HSLA were found to be lower than EDD steels (table 2). The grains

Table 2. Formability parameters of the steels investigated.

\begin{tabular}{|c|c|c|c|c|}
\hline Sl. No. & Steel & $\begin{array}{l}\text { Average strain } \\
\text { hardening exponent } \\
\text { (ii) }\end{array}$ & $\begin{array}{c}\text { Average plastic } \\
\text { strain ralio } \\
\text { (i) }\end{array}$ & $\begin{array}{c}\text { Planar } \\
\text { anisotropy } \\
(\Delta r)\end{array}$ \\
\hline- & -.....- & $\ldots$ & 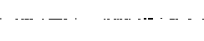 & (n) \\
\hline 1 & EDD & $0.22 \cdot 0.25$ & $1 \cdot 40 \cdot 1.90$ & $0.54-0.72$ \\
\hline 2 & HSCR & $0.18 \cdot 0 \cdot 19$ & $1 \cdot 20 \cdots 1 \cdot 40$ & $0.35 \cdot 0 \cdot 50$ \\
\hline 3 & L.PG & $0.204-0.207$ & $0.88-0.93$ & $-(0 \cdot 12-0 \cdot 20)$ \\
\hline 4 & AISI-304 & $0 \cdot 14.0 \cdot 45$ & 0.84 & -0.26 \\
\hline 5 & AISI-430 & $0 \cdot 18$ & 2.08 & 0.73 \\
\hline 6 & $\begin{array}{l}\text { Low } \mathrm{Ni} \\
\text { austenitic }\end{array}$ & 0.15 .0 .49 & 101 & -0.18 \\
\hline 7 & HSIA & $0 \cdot 176$ & 0.81 & $-0 \cdot 11$ \\
\hline
\end{tabular}
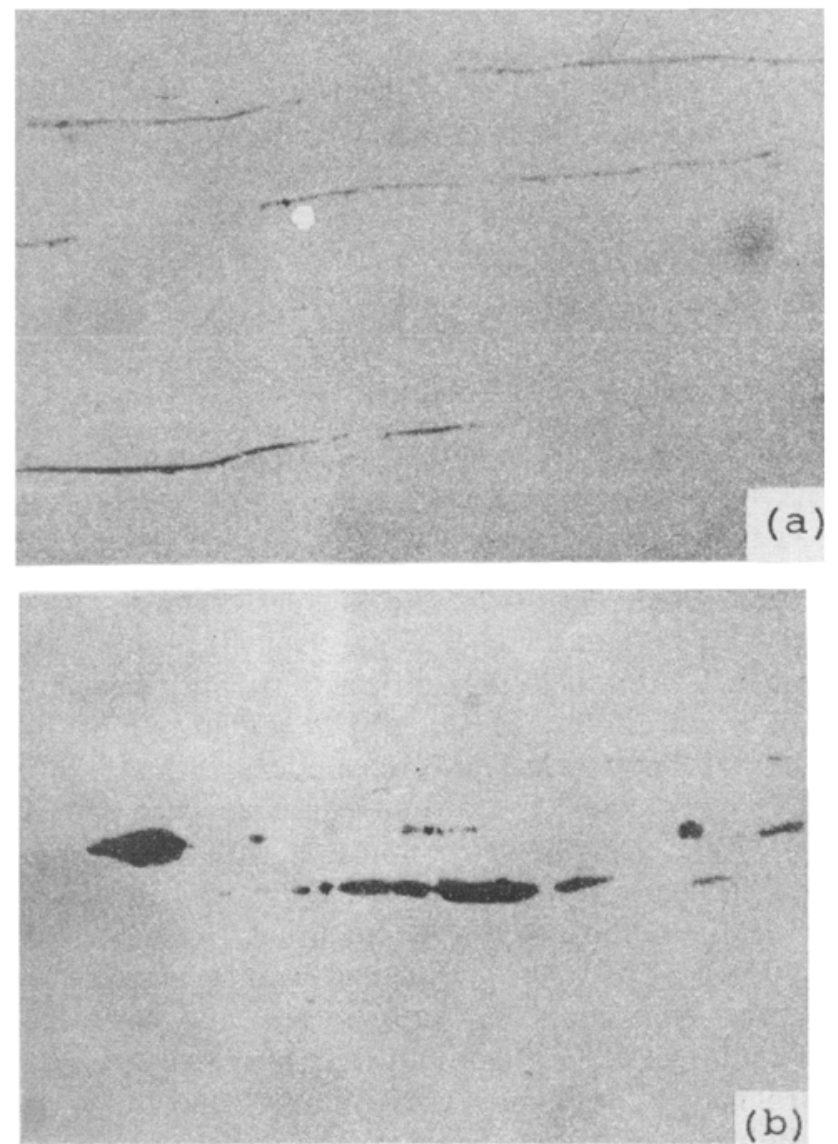

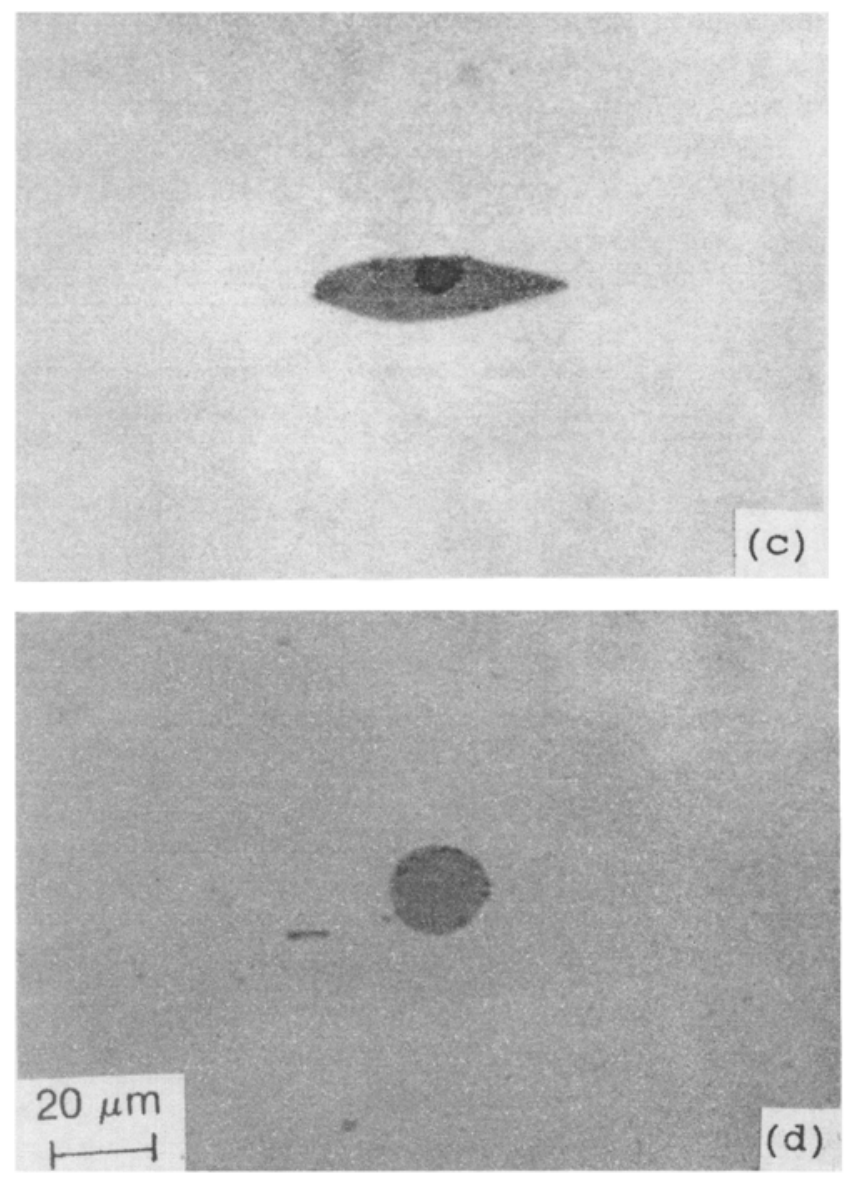

Figure 1. (a) MnS stringers in RE-free steel, (b) RE-enriched $\mathrm{MnS}$ stringers in $0.5 \mathrm{~kg}$ per ton of REM treated steel, (c) isolated RE-enriched $\mathrm{MnS}$ with an angular oxide inside in a $0.5 \mathrm{~kg}$ per ton of REM treated steel and (d) globular rare earth oxysulphide in $1.0 \mathrm{~kg}$ and $1.5 \mathrm{~kg}$ per ton of REM treated steel.

of these steels (between ASTM 9 to 11) were finer as compared to EDD steels. Moreover, these steels also contained higher solute elements as shown in table 1.

The effect of elongated $\mathrm{MnS}$ inclusions on ductility and stretchability of high strength low alloy steel is well established (Waudby 1978; Paul and Mishra 1992). The $\bar{n}$ value of HSLA steel was found to increase systematically from 0.176 for untreated steel to 0.192 for the $1.5 \mathrm{~kg}$ per ton of REM treated steel as shown in table 3. (The degree of sulphide shape control and cleanliness were improved with the REM addition (Paul et al 1982a)). The MnS stringers in untreated steel and their change in morphology for varying amounts of REM additions are shown in figure 1 . The increase in the $\bar{n}$ value was minimal for the $0.5 \mathrm{~kg}$ REM per ton of treated steel because of the presence of modified MnS stringers. With complete shape control and improved cleanliness associated with higher amount of REM additions, the $\bar{n}$ value increased significantly. Sulphide shape control had also resulted in greater improvement in the $\bar{n}$ value in the transverse direction (table 3). 
Table 3. Values of strain hardening exponent for varying amounts of REM addition.

\begin{tabular}{lcccc}
\hline $\begin{array}{l}\text { REM } \\
\text { added } \\
(\mathrm{kg} / \mathrm{ton})\end{array}$ & \multicolumn{3}{c}{ Strain hardening exponent $(n)$} \\
& $n_{0}$ & $n_{45}$ & $n_{90}$ & $\bar{n}$ \\
\hline Nil & 0.178 & 0.178 & 0.171 & 0.176 \\
0.5 & 0.176 & 0.179 & 0.173 & 0.177 \\
1.0 & 0.186 & 0.188 & 0.184 & 0.186 \\
1.5 & 0.189 & 0.195 & 0.188 & 0.192 \\
\hline
\end{tabular}

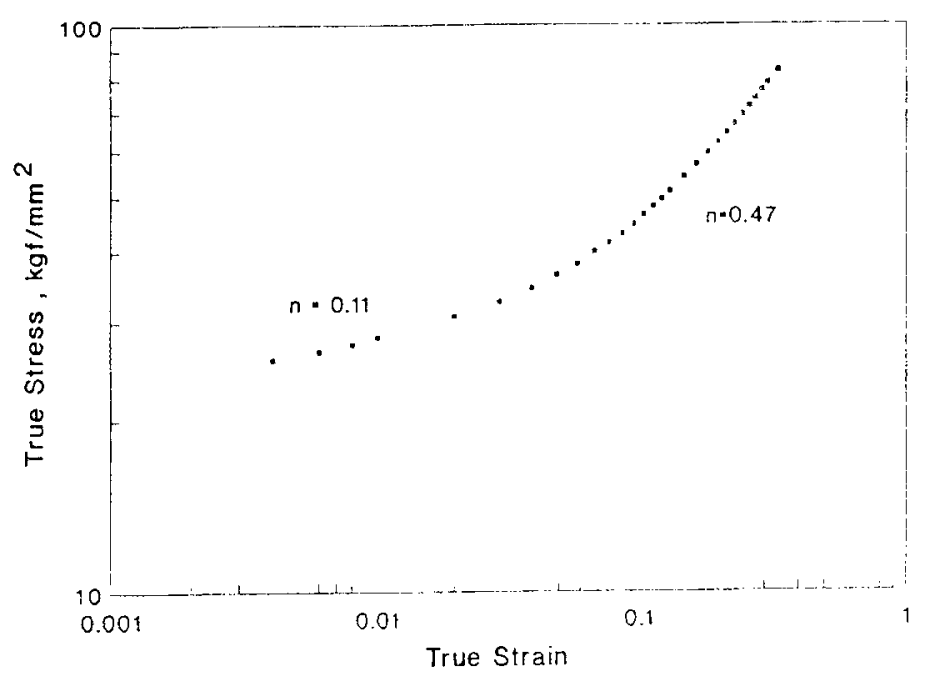

Figure 2. True stress vs true strain curve for steel AISI 304 in transverse direction.

The $\bar{n}$ values in two austenitic stainless steels (fcc) were found to vary with the degree of deformation which is different from other low carbon bcc steels. During the initial stage of straining, the work-hardening rate primarily depends upon the deformation of lattice structure and the $\bar{n}$ values obtained were low ( $0 \cdot 14$ for AISI 304 grade and $0 \cdot 15$ for low $\mathrm{Ni}$ austenitic steel) as shown in table 2. During continued straining, the austenite transformed into martensite and the flow stress increased rapidly because of the participation of martensite itself in the deformation process. This resulted in an increase in the work-hardening rates to 0.45 and 0.49 respectively as shown in table 2 . The degree of strain-induced martensite transformation and hence the work-hardening rate depends on the chemical composition (Pickering 1976). Because of more stable austenite, the work hardening rate is less for AISI 304 grade as compared to low $\mathrm{Ni}$ austenitic steel (table 2). A typical true stress vs true strain curve in logarithm scale for steel AISI 304 in transverse direction is shown in figure 2.

\subsection{Average plastic strain ratio $(\bar{r})$ and planar anisotropy $(\Delta r)$}

For better drawability, it is necessary that the material must have a low flow sirength in the plane of the sheet and a high strength in the direction perpendicular to the sheet i.e. 
thickness direction. The $\bar{r}$ which measures the property of having different strengths in the plane of the sheet and normal to the sheet, strongly depends on the preferred crystallographic orientation or texture developed (Whiteley et al 1961; Mishra and Darman 1982). It has been established (Vieth and Whiteley 1964) that a cube-on-corner texture with $\{111\}$ planes in the plane of the sheet gives rise to high $\bar{r}$ value, whereas a cube-on-face texture with $\{100\}$ planes parallel to the plane of the sheet reduces the $\vec{r}$ value. The $\bar{r}$ and $\Delta r$ values measured for the various grades of steels are shown in table 2. For discussion, the steels can be classified into two categories: bcc (EDD, HSCR, LPG. HSLA and ferritic stainless steels) and fcc (austenitic stainless steels).

Amongst the bcc steels, there is a distinct difference in the $\bar{r}$ and $\Delta r$ parameters for the cold-rolled steels (EDD, HSCR and ferritic stainless steel) and the hot-rolled steels (LPG and HSLA). The $\bar{r}$ values of EDD steels were in the range of 1.4 to 1.90 (table 2). Cold rolled Al-killed EDD sheet steels are well established to develop sharp recrystallization textures of $\{111\}$ type after annealing by preferred nucleation mechanism (Mishra and Darmann 1982: Huchinson 1984). The evaluation of (110) pole figures for EDD steels also showed sharp $\{111\}$ texture (figure 3 ), which resulted in high $\bar{r}$ values. This is also true to some extent with the high-strength cold-rolled sheets. The evaluation of (110) pole figures showed fairly strong $\{111\}$ texture (Paul et al 1993), which resulted in $\bar{r}$ in the range of $1 \cdot 2$ to $1 \cdot 40$. It can be seen from table 2 that for both EDD and HSCR sheets, the $\Delta r$ values were positive and fairly high. This indicates that for both steels concerned, the favourable crystallographic texture is much stronger in

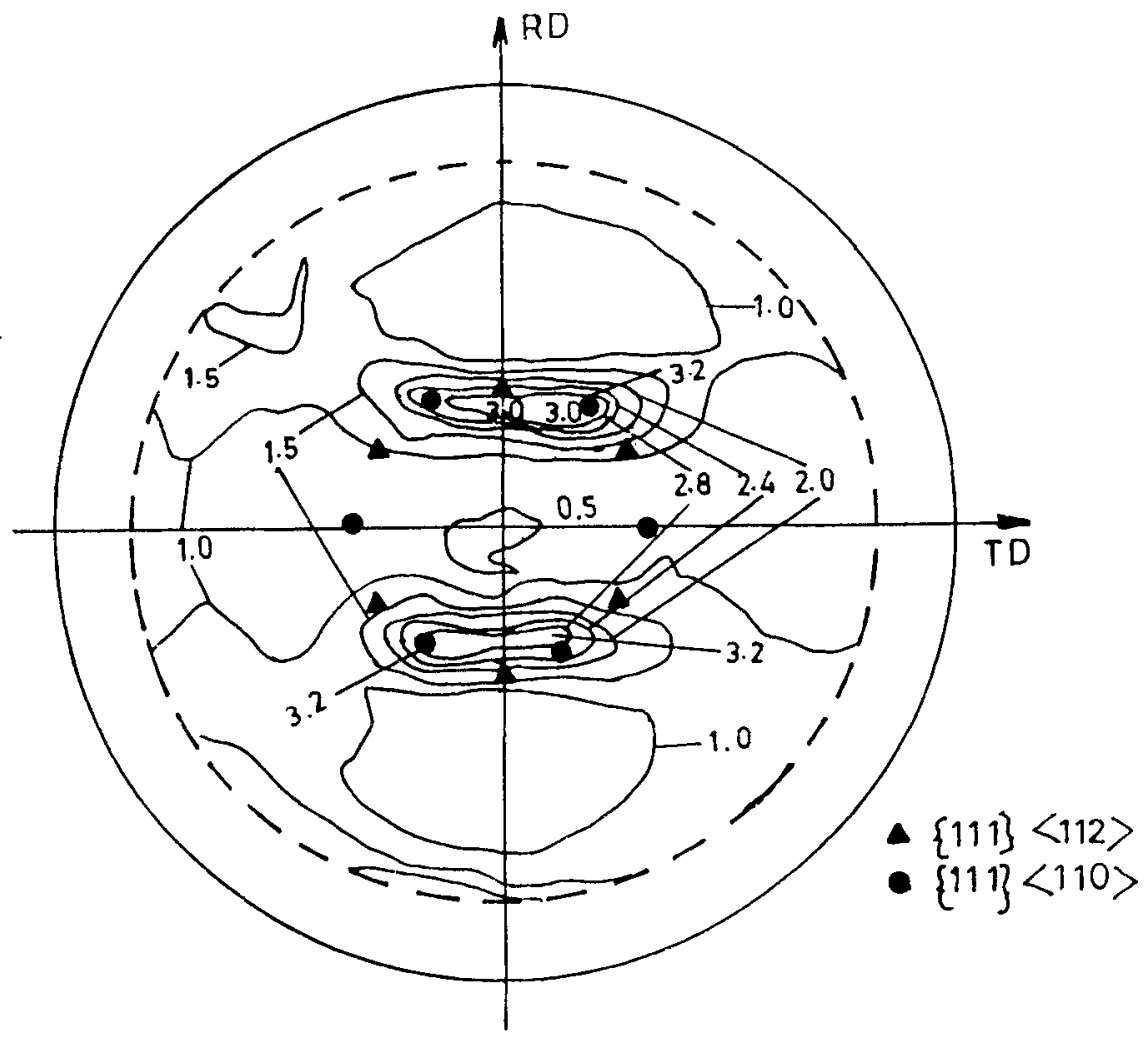

Figure 3. (110) pole figure of $1.6 \mathrm{~mm}$ fully processed EDD steel showing strong $\{111\}$ texture. 
Table 4. Values of plastic strain ratio for varying amounts of REM addition.

\begin{tabular}{|c|c|c|c|c|c|}
\hline \multirow{2}{*}{$\begin{array}{l}\text { REM } \\
\text { added } \\
\text { (kg/ton) }\end{array}$} & \multicolumn{4}{|c|}{ Plastic strain ratio } & \multirow{2}{*}{$\begin{array}{c}\text { Planar } \\
\text { anisotropy } \\
(\Delta r)\end{array}$} \\
\hline & $r_{11}$ & $r_{45}$ & $r_{* 0}$ & $\bar{r}$ & \\
\hline $\mathrm{Nil}$ & 0.68 & 0.86 & 083 & 0.81 & $-0 \cdot 11$ \\
\hline 0.5 & 0.63 & 0.91 & 0.76 & 0.80 & -0.22 \\
\hline 1.0 & 0.61 & 0.97 & 0.69 & $0 \cdot 81$ & -032 \\
\hline $1 \cdot 5$ & 0.60 & $1 \cdot 0$ & 0.65 & 0.81 & -0.38 \\
\hline
\end{tabular}

the $0^{\circ}$ and $90^{\circ}$ orientations than in the $45^{\circ}$ orientation and ears will form at $0^{\circ}$ and $90^{\circ}$ to the rolling direction. It has also been reported (Keeler 1972) that a material of high $\vec{r}$ value is usually associated with a high $\Delta r$ value. In the case of ferritic stainless steel (cold-rolled and annealed) a high $\bar{r}$ value of 2.08 was observed (table 2). This is presumably due to the very sharp $\{111\}$ type texture which develops (Miyaji and Watanabe 1980) in such steel by the mechanism of in situ recrystallization. Melander et al (1985) also reported high $\bar{r}$ and $\Delta r$ values for ferritic stainless steel.

On the other hand, the hot-rolled steels (LPG and HSLA) exhibited very low $\bar{r}$ values $(<1 \cdot 0)$ as well as low $\Delta r$ values as shown in table 2 . This arises on account of weak crystallographic texture generally associated with hot-rolled steels (Paul and Mishra 1992). The $\bar{r}$ value of HSLA steel also remained unchanged after REM additions for sulphide shape control. However, the $r_{45}$ value was found to increase systematically at the expense of $r_{0}$ and $r_{90}$ with the increasing rate of REM addition. This resulted in greater planar anisotropy for higher amount of REM addition (table 4). The $\Delta r$ values obtained were negative, indicating the formation of ears at $45^{\prime \prime}$ to the rolling direction during drawing operation.

With regard to fec austenitic stainless steels, both low $\bar{r}$ values and negative $\Delta r$ values were obtained (table 2). Similar results have also been reported by Melander et al (1985). In austenitic stainless steels, the texture that develops after cold rolling and annealing is of the type $\{110\}\langle 112\rangle$ and $\{110\}\langle 001\rangle$. This texture is not favourable for giving high $\bar{r}$ value (Donadille et al 1989 ).

\subsection{Forming limit diagrams}

Forming limit diagram (FLD) is a useful guide in predicting formability since it denotes the end of useful deformation. A high level of FLD generally indicates good formability. The forming limit diagrams of all the seven grades of steel were evaluated and each grade was found to possess a unique FLD. The FLD's of all the six EDD heats were very similar. However, the level of FLD as measured by plane strain intercept $\left(\mathrm{FLD}_{0}\right)$ was found to rise with the increase in sheet thickness. The $0.8 \mathrm{~mm}$ thick EDD sheets showed the lowest $\mathrm{FLD}_{0}$ of about $40 \%$ as compared to $50 \%$ for the $2.0 \mathrm{~mm}$ thick sheets. Others (Keeler and Brazier 1977; Hiam and Lee 1978) have also shown that an increase in sheet thickness results in higher limiting strains. Since the width of the necked zone is approximately equal to the sheet thickness, the necking is slow in thicker sheets (Schedin et al 1982). Thus the increased sheet thickness improves the ability to 


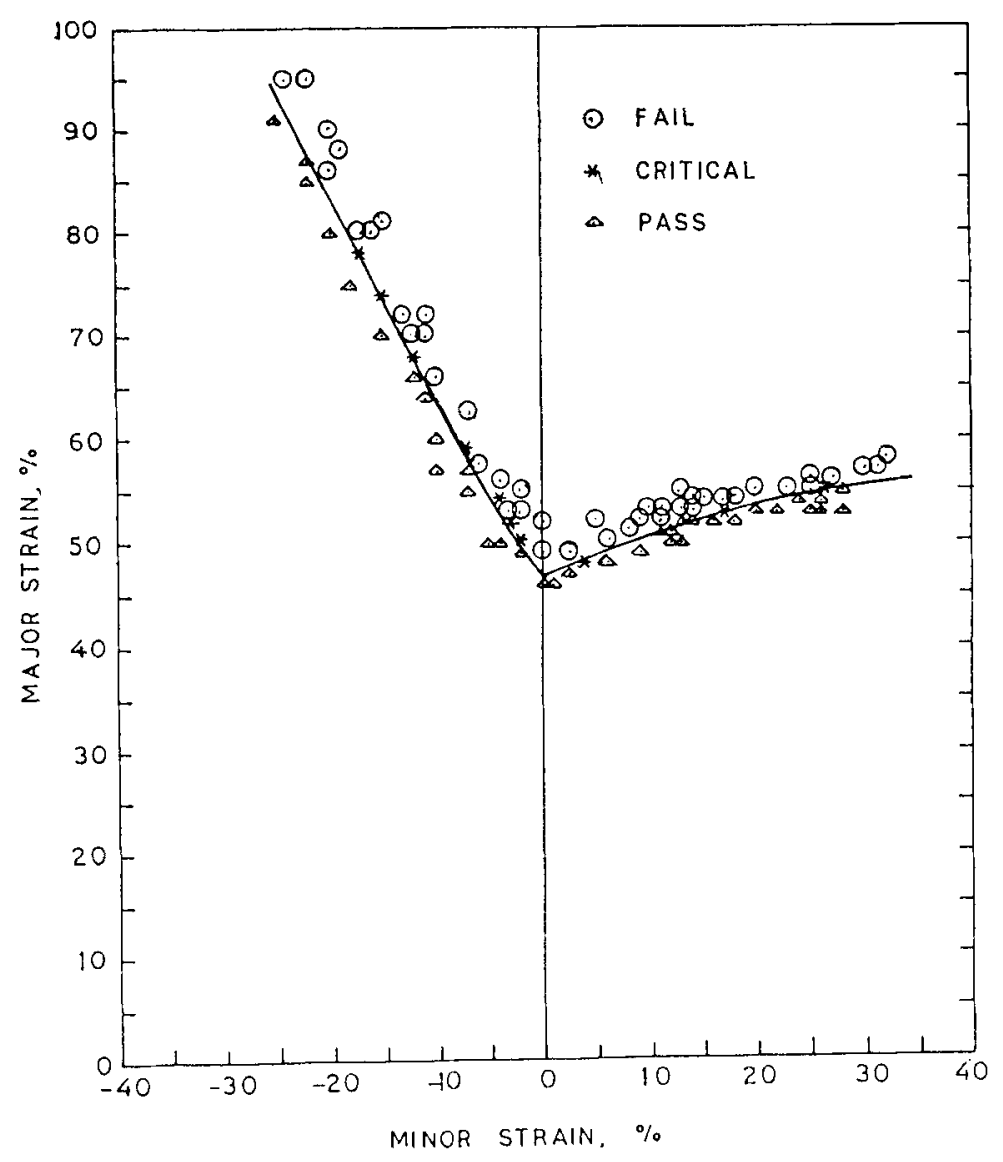

Figure 4. Forming limit diagram of $1.40 \mathrm{~mm}$ EDD steel.

resist the localized necking of instability, and, hence, results in higher level of FLD. The forming limit diagram of $1.4 \mathrm{~mm}$ EDD steel is shown in figure 4. The FLD's of all the six heats were found to lie within the Keeler-Goodwin band for low carbon EDD quality steels.

The forming limit diagrams of three $1 \mathrm{~mm}$ thick high-strength cold-rolled steels were found similar. The formability parameters $(\bar{r}$ and $\bar{n})$ of HSCR steels were inferior to those of EDD steels (table 2). The level of FLD for this steel was also found to be lower than that of EDD steels (figure 5) which may be attributed to the lower $\bar{n}$ value. Reis et al (1982) also reported a similar FLD for the same grade of high strength cold rolled sheets. The FLD of the HSCR steel indicates its suitability for moderate forming applications. The formability properties of three hot rolled LPG steels investigated were similar (table 2) and the FLDs of these steels were also found identical. This demonstrates the excellent consistency in the quality of the product. Figure 6 shows the typical forming limit diagram of $2.85 \mathrm{~mm}$ LPG sheets.

The forming limit diagrams of three grades of stainless steels, viz. AISI 304 austenitic, AISI 430 ferritic and low Ni austenitic, are shown in figures 7,8 and 9 respectively. The FLDs of all the stainless steels exhibited maxima in the positive minor strain region, 


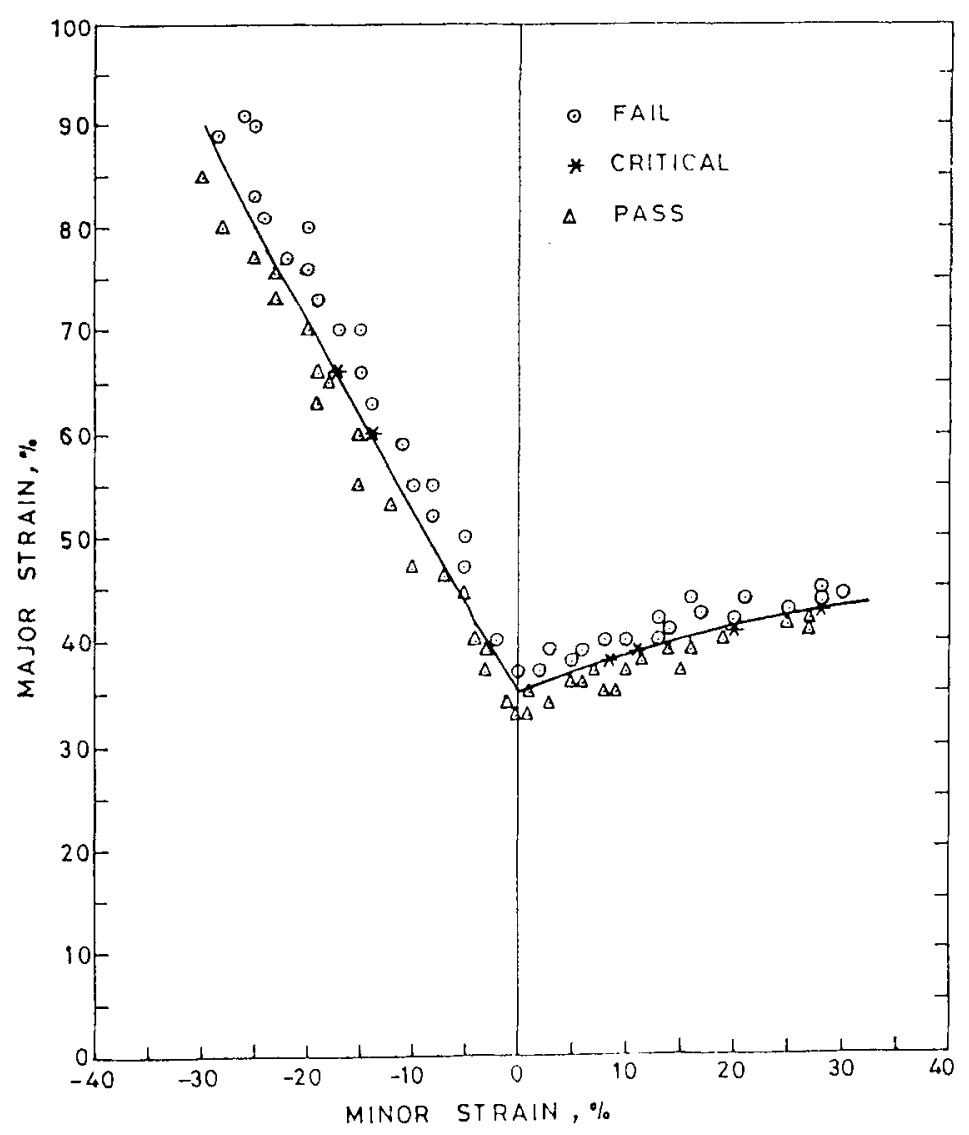

Figure 5. Forming limit diagram of $1.0 \mathrm{~mm}$ HSCR steel.

which is different from the FLDs of other low carbon steels investigated. Hecker (1977) also reported similar curves for these steels. In austenitic stainless steel, the maxima and the subsequent fall in the FLD may be attributed to the slowing down of the strain induced transformation (Hecker et al 1982) from the fcc austenite to bcc martensite. The percentage martensite formed during stretching of $200 \times 200 \mathrm{~mm}$ specimens of AISI 304 and low Ni austenitic stainless steels were measured and found to be 16 and 20 respectively. The microstructure of the deformed steel of AISI 304 grade near the fracture revealed the presence of both austenite and martensite (figure 10). The SEM fractograph of the fracture surface also showed a mixed mode of fracture (figure 11) consisting of ductile dimples (zone A) and cleavage facets (zone B). After the maxima, abrupt failures indicative of brittle fracture were observed when the positive minor strain level exceeded $20 \%$ for AISI 304 grade and $15 \%$ for low Ni austenitic stainless steel (figures 7 and 9 ). The level of FLD for AISI 304 grade (56.5\% strain) was found to be higher than low Ni austenitic steel ( $52 \%$ strain), indicating its superior formability. The austenitic stainless steels showed very high level of FLDs due to the high $\bar{n}$ values (table 2). With a poor $\bar{n}$ value $(0 \cdot 18)$, the ferritic stainless steel had shown a low level of FLD (figure 8 ).

The forming limit diagrams of untreated HSLA steel and $1.5 \mathrm{~kg}$ per ton of REM treated steel are shown in figure 12. The presence of large elongated inclusions can 


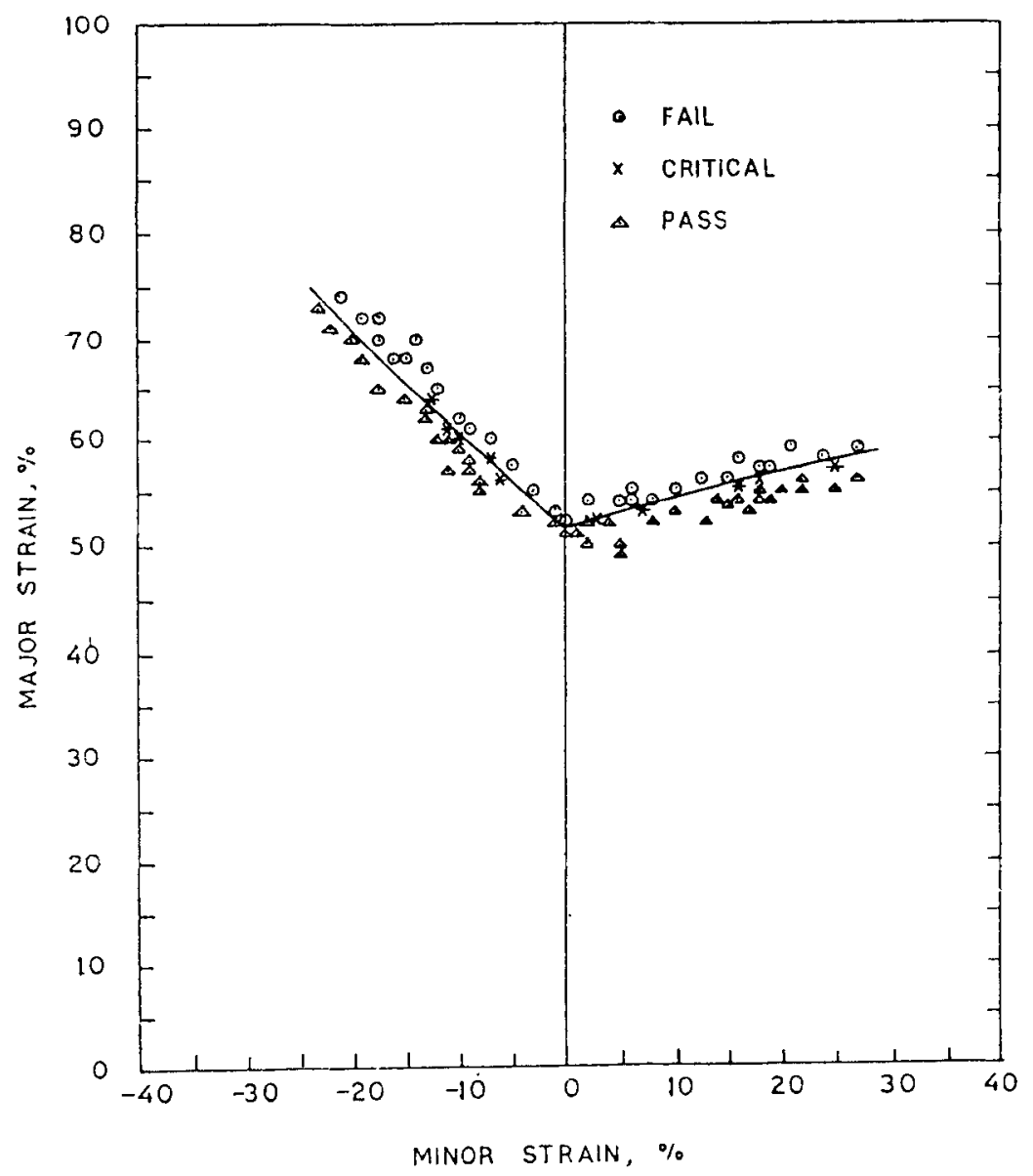

Figure 6. Forming limit diagram of $2.85 \mathrm{~mm}$ LPG steel.

result in premature fracture in HSLA steel. Sulphide shape control was found to result in significant improvement in the level of FLD. The influence of sulphide shape modification on the critical strain level was also more noticeable in the biaxial-stretch quadrant than under plane strain condition (figure 12). The $\bar{r}$ values being same for both REM treated and untreated steels, it would appear that the improvement in the level of FLD for REM treated steel was primarily on account of higher $\bar{n}$ value (table 3 ).

\subsection{Bend formability}

The bend formability is another important parameter for cold forming applications, particularly for HSLA steels used for automotive parts e.g. chassis members require good transverse bendability. Usually close bend properties are achieved in cold-rolled and annealed sheet steels used for stamping applications. In the case of hot rolled HSLA steel, the presence of MnS stringers drastically reduce (Paul et al 1982a) the bendability in transverse direction. The effect of sulphide shape control on bend 


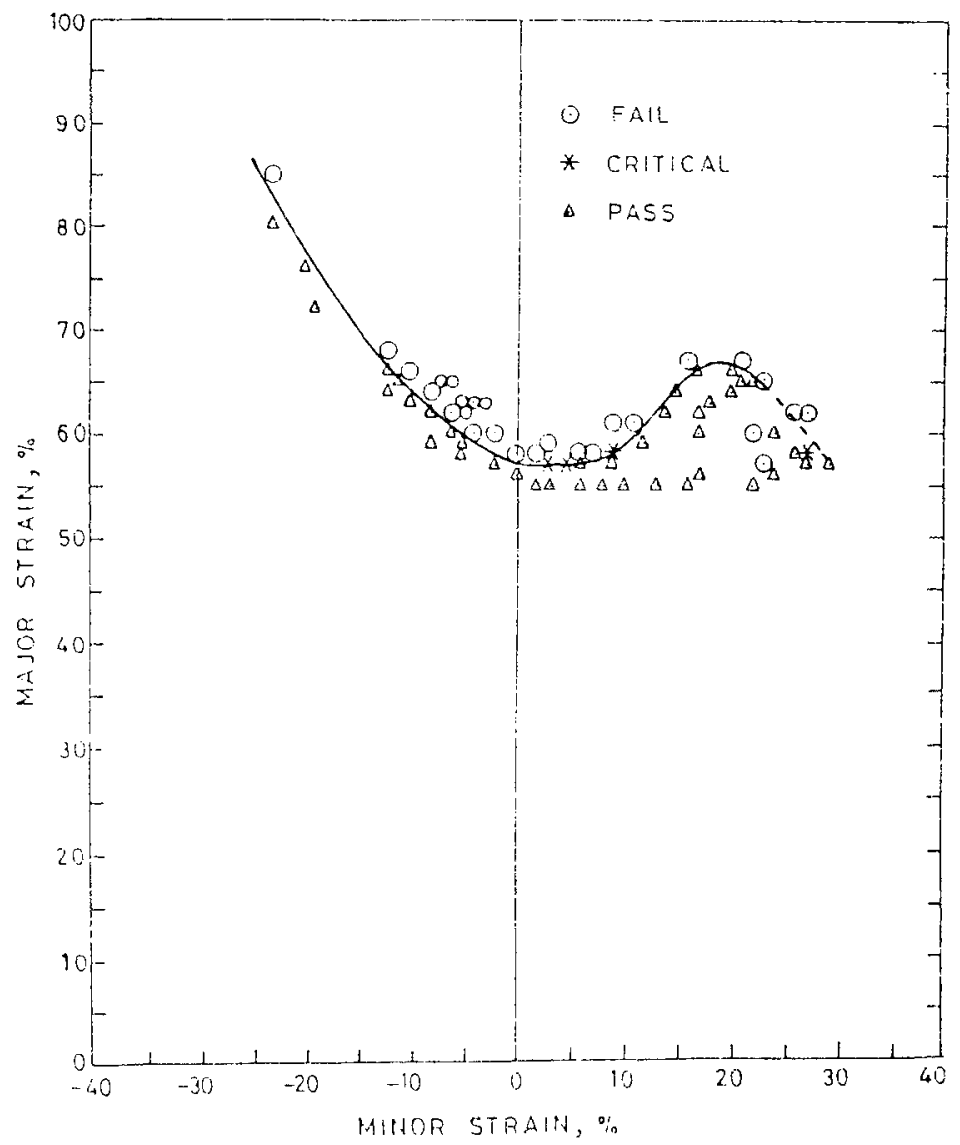

Figure 7. Forming limit diagram of $1.0 \mathrm{~mm}$ AISI 304 austenitic stainless stecl.

formability is illustrated in figure 13. The untreated steel with elongated manganese sulphides (figure 1) exhibited severe cracking when bent over a radius equal to twice the sheet thickness $(2 t)$, with the axis of the bend parallel to the rolling direction. On the other hand, all REM treated steels showed no crack even after bending by $180^{\circ}$ (close $t$ ) as shown in figure $13 \mathrm{~b}$.

\subsection{Press performance}

Extra deed drawing sheet steels are extensively used in the automobile industries for forming various critical components. These steels are characterized by their superior drawability $(\bar{r}=1.4$ to 1.9$)$ and stretchability $(\bar{n}=0.22$ to 0.25$)$ properties. The level of FLD is also higher for this steel as compared to other low carbon steels. Press trials were conducted in the stamping plants of leading automobile manufacturers for forming various components. Some of the critical components were oil sump (upper), oil catcher, push rod chamber cover etc. of a heavy duty truck, tonneau outer, door inner, trunk lid inner, dog leg etc. of an ambassador car. A combination of stretching 


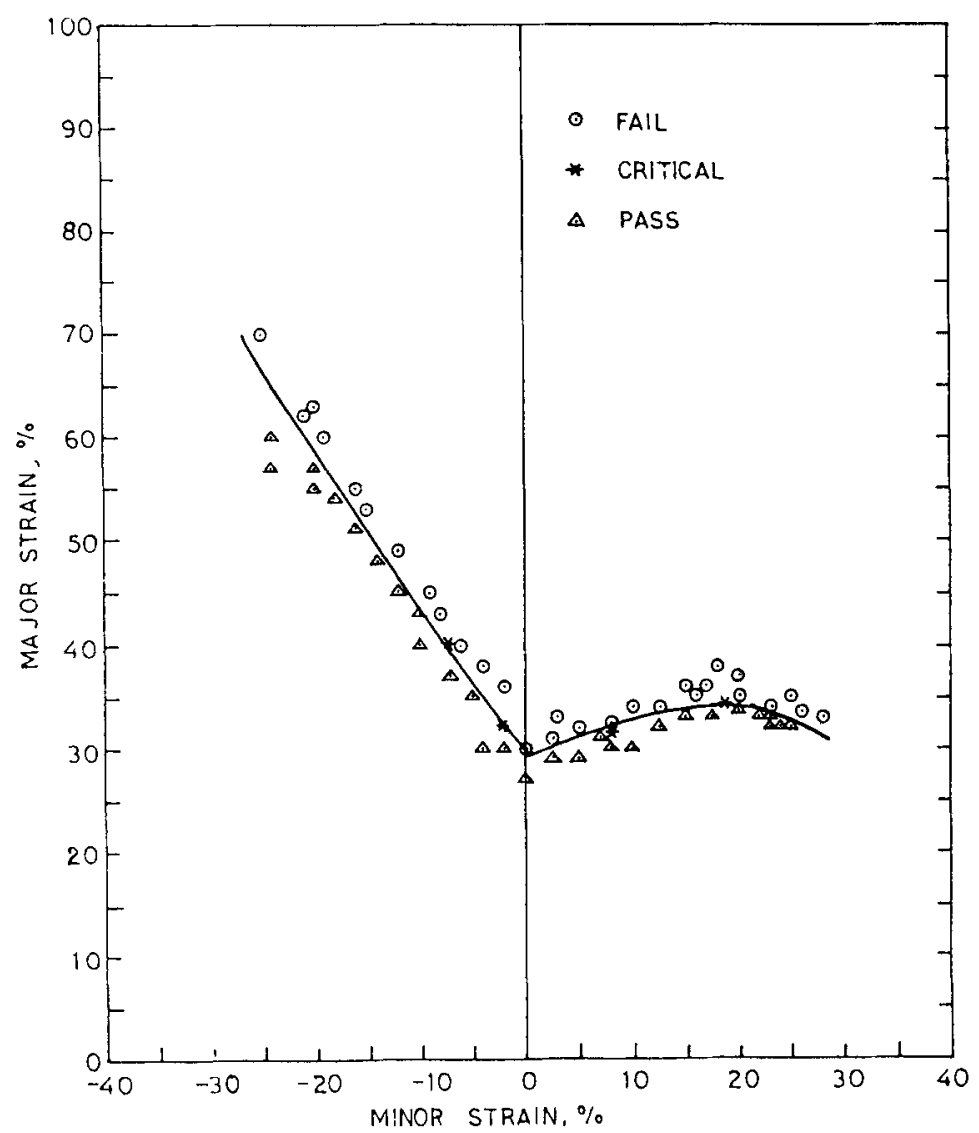

Figure 8. Forming limit diagram of $1.0 \mathrm{~mm}$ AISI 430 ferritic stainless steel.

and drawing was encountered for forming these components and the steels with good $\bar{r}$ and $\bar{n}$ behaved well. Figure 14 shows the photograph of a oil sump (upper) where both drawing and stretching were involved where as figure 15 shows the photograph of an oil catcher, where stretching was mainly predominant.

Micro-alloyed high-strength cold-rolled sheet steels are also used for the manufacture of various auto-body panels for the improvement of car safety as well as weight reduction. The formability parameters $(\bar{r}, \bar{n}$ and level of FLD) of this steel indicated that it can be used only for moderate forming applications. In view of these, press trials were conducted for forming components like rear floor panel and front floor cross member of a passenger car and dash panel of a jeep and good results were obtained. Figure 16 shows the photograph of a rear floor panel.

The press performance trials of AISI 304 grade austenitic stainless steels were monitored for forming water filters and pressure cooker. It would be worth while to first describe in brief the methods of forming water filter and pressure cooker. The forming of a water filter chamber ( 27 litre capacity) is done in two stages in a hydraulic press. In the first stage, a circular blank of $596 \mathrm{~mm}$ diameter (sheet thickness $0.5 \mathrm{~mm}$ ) is drawn into a flat bottom cup of $320 \mathrm{~mm}$ diameter and $220 \mathrm{~mm}$ height as shown in figure 17 . The diameters of the die and punch of the hydraulic press are $321.4 \mathrm{~mm}$ and $320 \mathrm{~mm}$, 


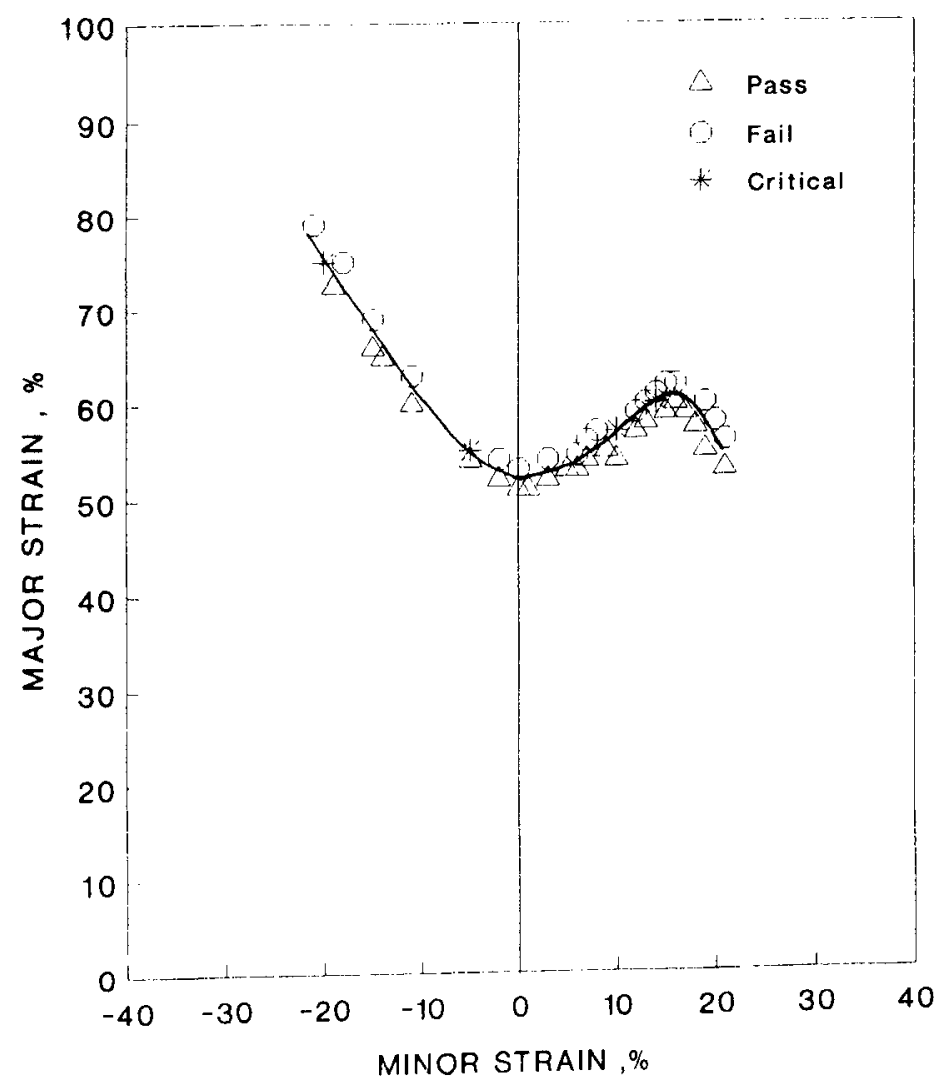

Figure 9. Forming limit diagram of $1.0 \mathrm{~mm}$ low $\mathrm{Ni}$ austenitic stainless steel.

respectively. The speed of drawing is about $20 \mathrm{~mm} / \mathrm{sec}$. The diameter of the cup at the bottom is $260 \mathrm{~mm}$. During the first stage of forming, the lubricant used is drawmat compound, which also keeps the temperature below $40^{\circ} \mathrm{C}$. After the first stage of forming, the edge of the cup is trimmed by about $5 \mathrm{~mm}$. The cup is then redrawn into another flat bottom cup of $260.5 \mathrm{~mm}$ diameter and $265 \mathrm{~mm}$ height during the second stage of forming. The soap solution is used as lubricant. After this stage, the edge is again trimmed by $5 \mathrm{~mm}$ and then beading is done. After beading, the chamber (cup) is polished first by brushing and then by buffing. The stages of forming of a chamber of a water filter are shown in figure 17.

The body of a pressure cooker is also formed by two drawing operations followed by flattening of the flange to $90^{\circ}$ and subsequently rubbing of the flange as shown in figure 18 .

Blanks were prepared from various sheets of AISI 304 grade belonging to different heats and press trials for forming of water filter and pressure cooker were monitored. The percentage of strain induced martensite formed at various locations after different stages of forming were also measured. The rejections during forming of water filter were basically due to two reasons---formation of wrinkle and rough surface. The formation of wrinkles could be attributed to the operational characteristics of the press such as, die-punch clearance or insufficient blank holding pressure. The extent of strain-induced 


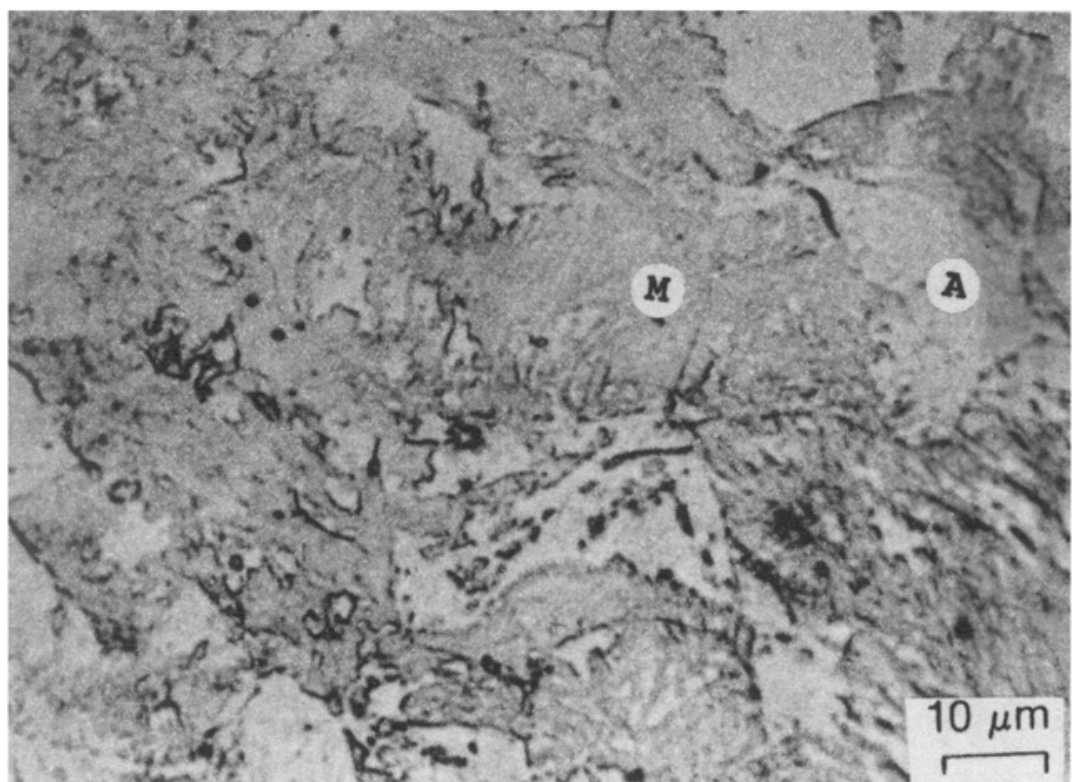

Figure 10. Microstructure showing the presence of both austenite $(A)$ and martensite $(M)$ for steel AISI 304.

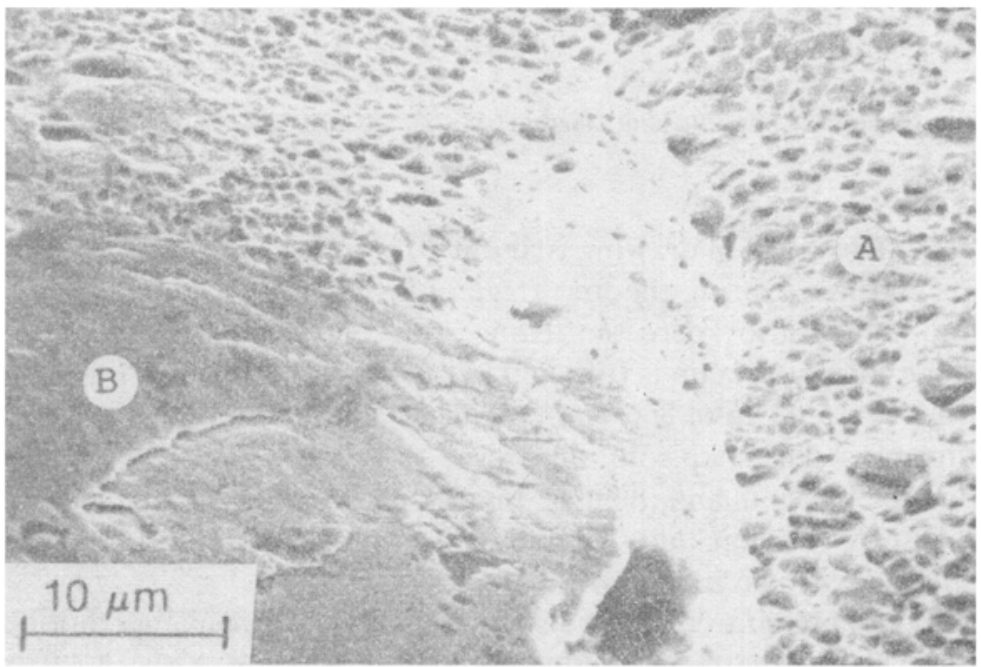

Figure 11. SEM fractograph showing a mixed mode of fracture

martensite formation was also observed to be higher in the region of the wrinkles. The formation of rough surface, known as 'orange peel effect' is due to coarser grains (greater than ASTM no. 6). This can be controlled by optimizing the final annealing temperature and time. 


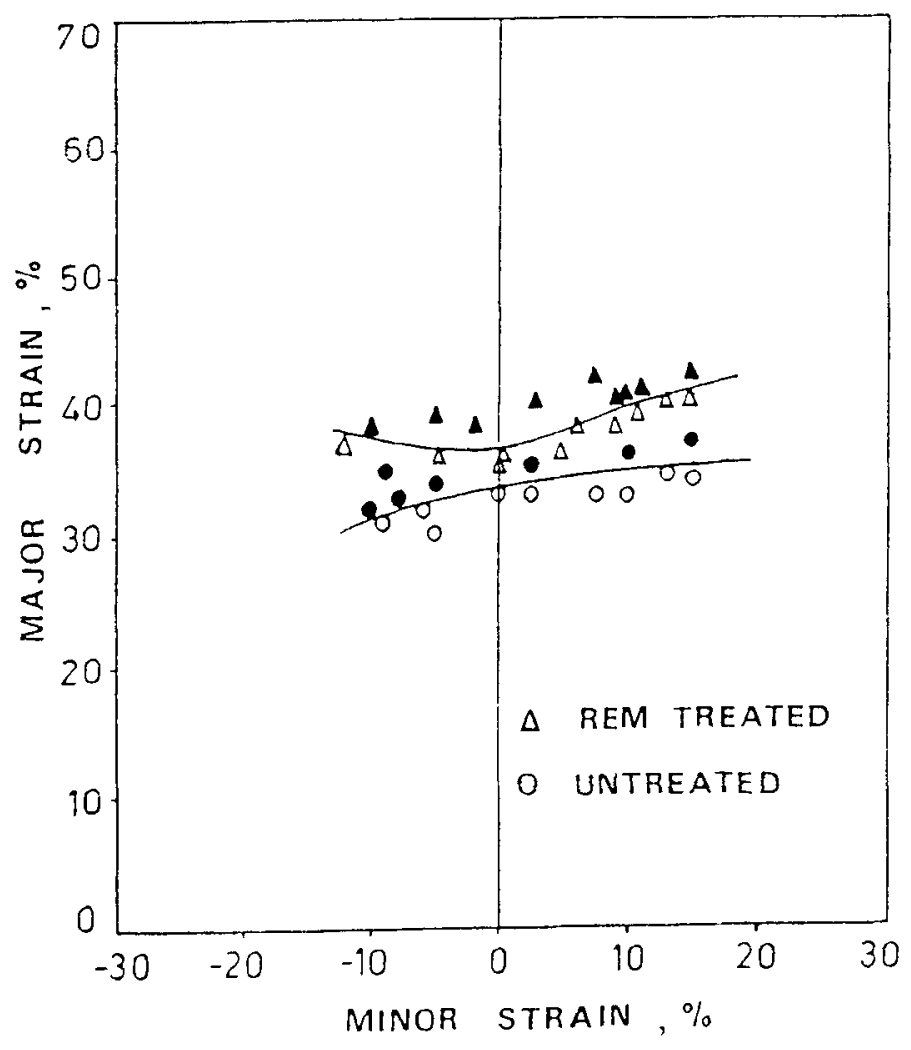

Figure 12. Forming limit diagram of HSL,A steels (thickness $2.5 \mathrm{~mm}$ ).

The failure of material during forming of pressure cooker was found to be of broadly two types: crescent-shaped crack formation on the cup wall and cracking at the flange. The presence of sliver-type defects on the sheet surface was found to be responsible for crescent-shaped crack formation on the cup wall. On the other hand, cracks were found to develop during the final bending operation of the flange whenever the amount of strain induced martensite formation exceeded a critical level of $17 \%$ in the flange. Hence the chemistry of AISI 304 steel meant for manufacturing the pressure cooker has to be carefully controlled to limit the extent of martensite formation below $17 \%$ after forming.

\section{Summary}

(l) The formability parameters $(\bar{r}$ and $\bar{n})$ and forming limit diagrams of various press forming sheet steels such as extra deep drawing quality, high strength cold rolled, LPG grade, austenitic as well as ferritic stainless and HSLA, have been evaluated in the laboratory.

(II) The strain hardening exponent values for austenitic stainless steels were found to vary with the degree of deformation. The increase in rate of work hardening at the later stage was associated with the formation of strain induced martensite. 

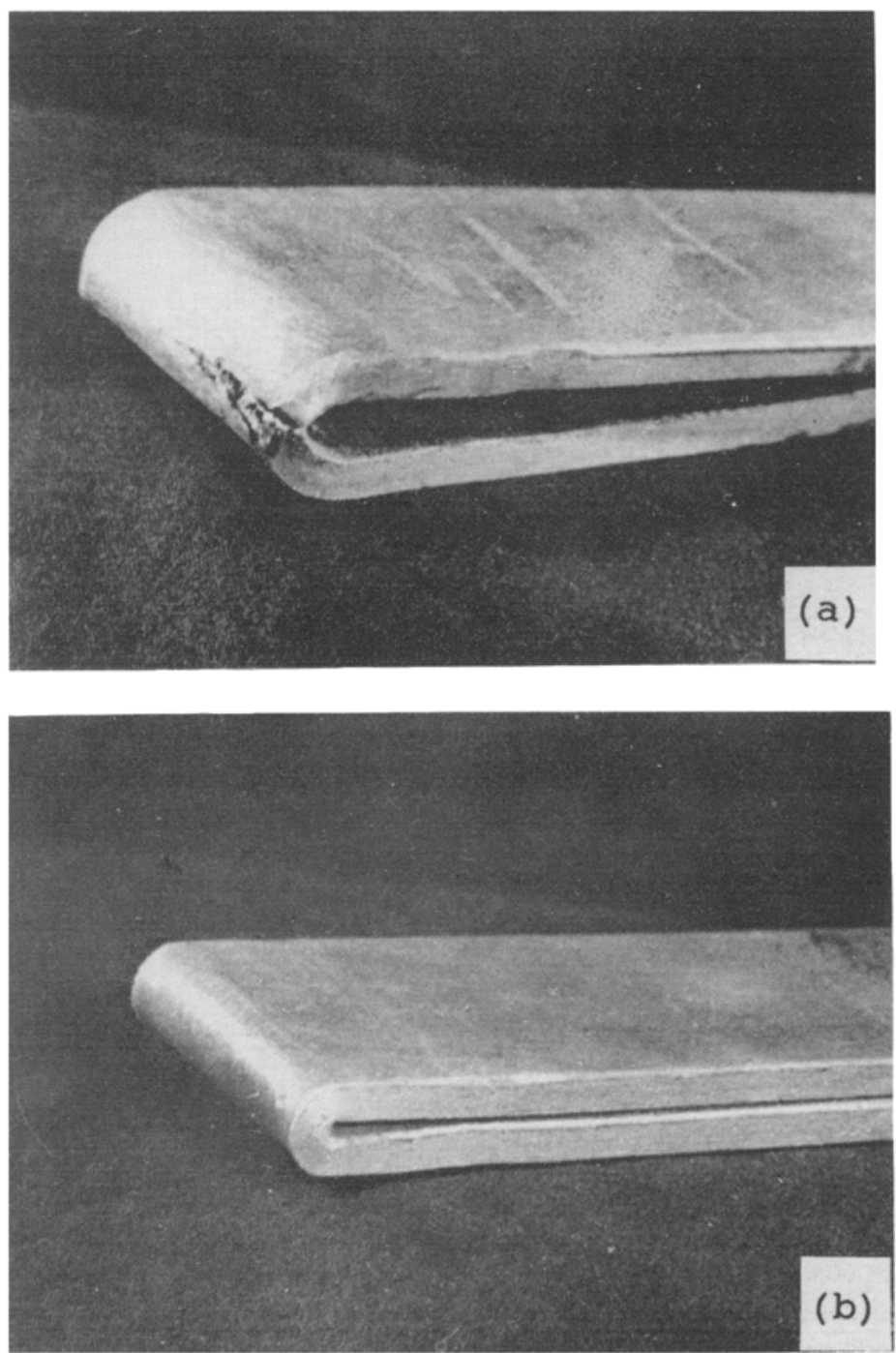

Figure 13. Effect of sulphide shape control on the transverse bend formability: (a) untreated HSLA steel and (b) REM treated steel.

(III) The sulphide shape control with REM addition resulted in higher $\bar{n}$ value whereas $\bar{r}$ remained unchanged.

(IV) The shape and level of FLD were found to be different for each grade of steel.

(V) The level of FLD was found to depend on sheet thickness and strain hardening exponent.

(VI) The level of FLD for austenitic stainless steel was found highest due to its intrinsically high $\bar{n}$ value. Ferritic stainless steel with poor $\bar{n}$ value had shown the lowest level of FLD amongst all the cold-rolled and annealed sheets. 


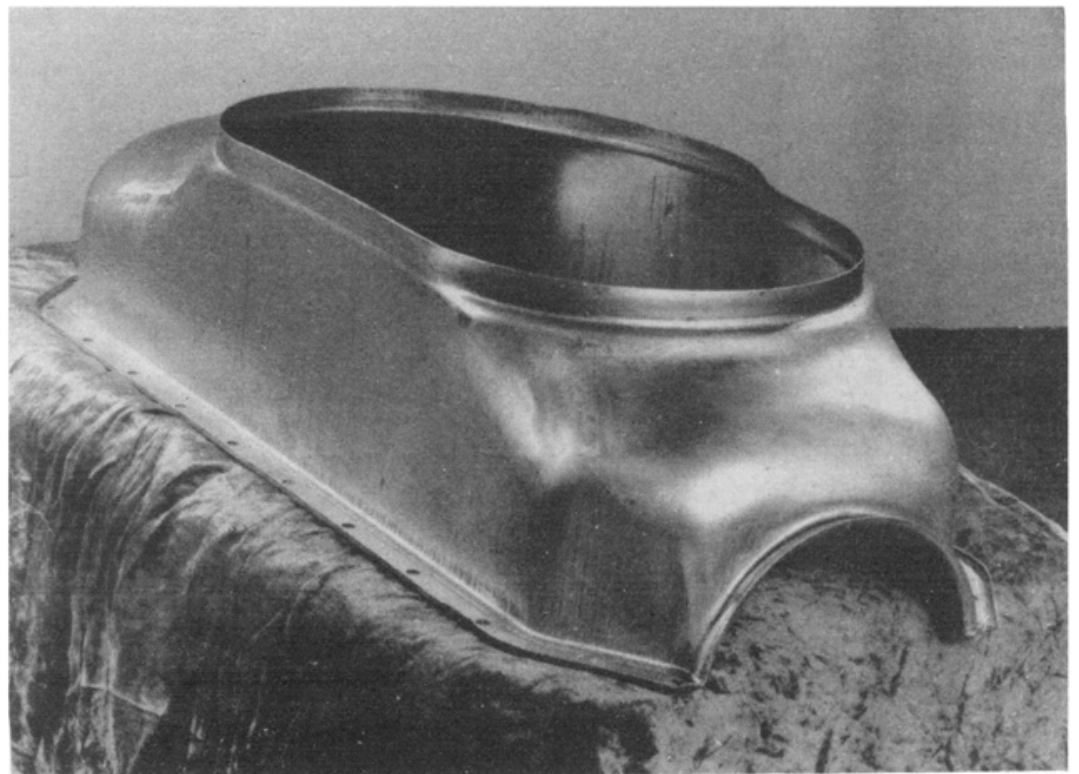

Figure 14. Photograph of oil sump (upper) of a heavy duty truck press-formed from EDD steel.

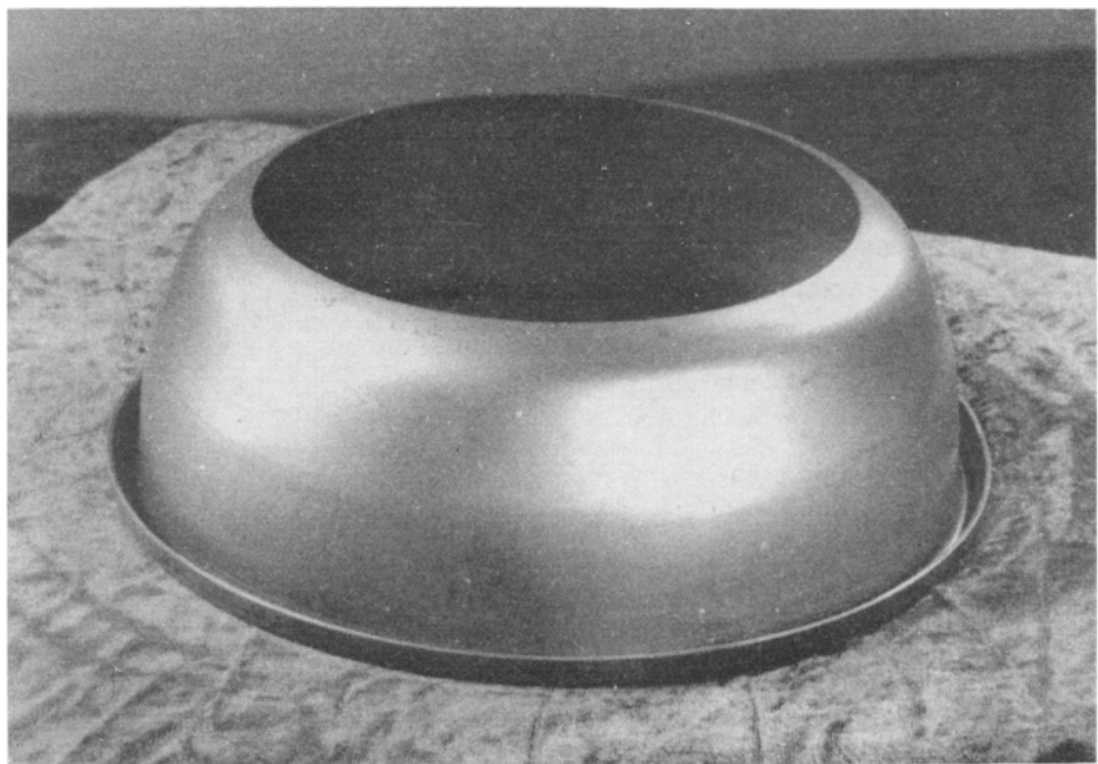

Figure 15. Photograph of oil catcher of a heavy duty truck press-formed from EDD steel.

(VII) The transverse bend formability for HSLA steel was found to improve remarkably with sulphide shape control.

(VIII) Extra deep drawing quality sheet steels with high $\bar{r}$ and $\bar{n}$ were found to behave well during stamping of critical auto-body components. 


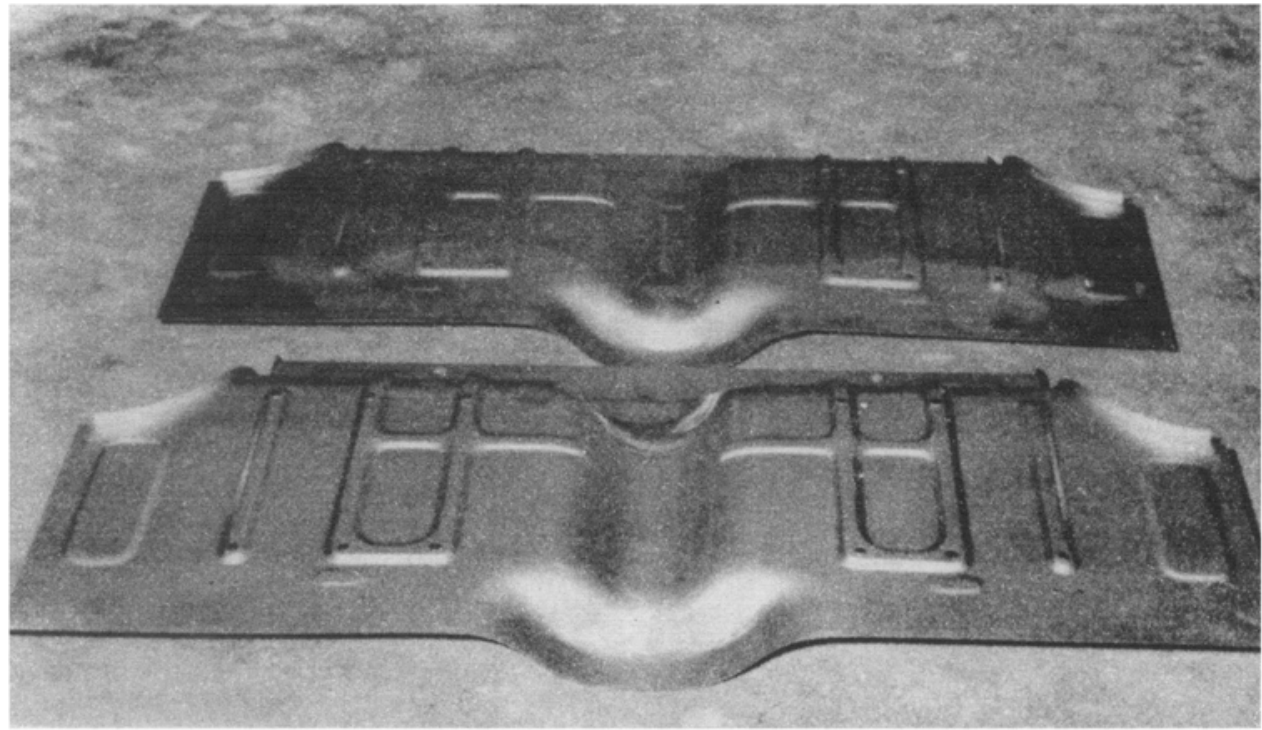

Figure 16. Photograph of rear floor panel of a passenger car press-formed from HSCR steel.
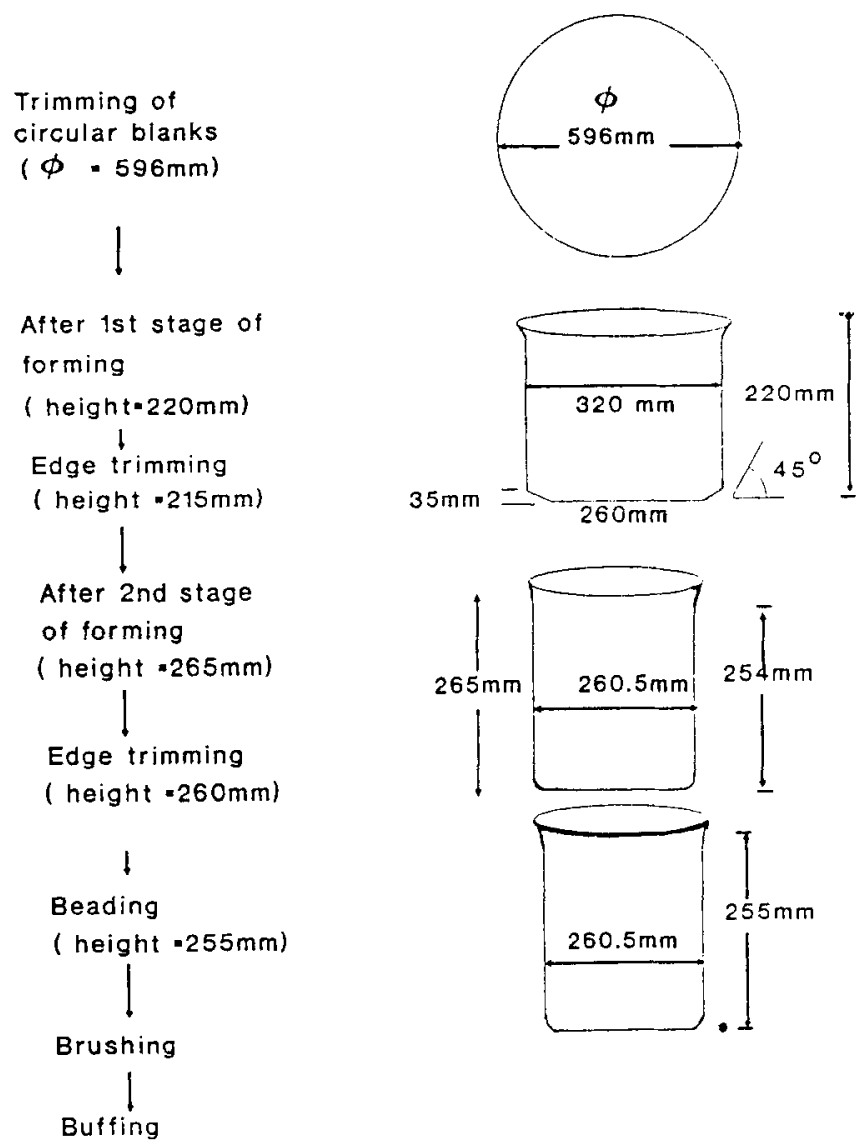

Figure 17. Stages of forming of a water filter chamber of 27 litre capacity. 

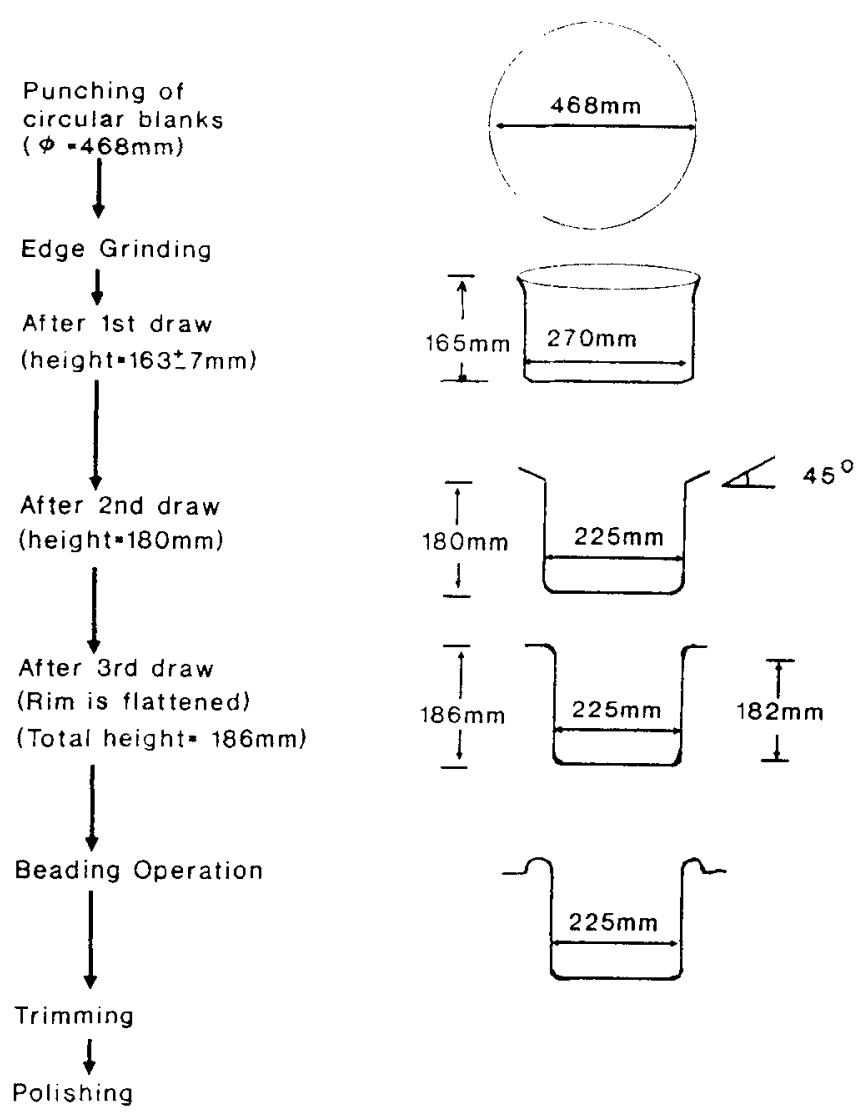

Figure 18. Stages of forming of a pressure cooker.

(IX) The rejections during forming of water filter were due to formation of wrinkles and rough surface. The formation of wrinkles could be attributed to the operational characteristics of the press. The formation of rough surface was due to coarser grains $(>44 \mu \mathrm{m})$.

(X) The failure of materials during manufacturing of pressure cooker was found due to formation of crescent-shaped crack on the cup wall and cracking at the flange. While the former was because of the presence of slivers on the sheet surface, the latter was related to the formation of more strain induced martensite $(>17 \%)$.

\section{References}

Blickwede D J 1968 Trans. ASM 61653

Blickwede D J 1984 Trans. Iron Steel Inst. Jpn 24687

Donadille C, Valle R, Dervin P and Penelle R 1989 Acta Metall. 371547

Goodwin G M 1968 SAE Paper 680093

Hecker S S 1975 Sheer Met. Ind. 52671

Hecker S S, Stout M G, Staudhammer K P and Smith J L 1982 Metall. Trans. A13 619

Hiam J and Lee A 1978 Sheet Met. Ind. 55631

Hutchinson W B 1984 Int. Metals Rev. 2925

Keeler S P 1965 Sheet Met. Ind. 42683 
Keeler S P 1972 Understanding sheet metal formability, Seminar St. Louis Chapter (Lindell Boulevard: ASM) p. 24

Keeler S P and Brazier W G 1977 Micro Alloying 75 (New York: Union Carbide Corporation) p. 517

Lankford W T, Snyder S C and Bauscher J A 1950 Trans ASME 421197

Melander A, Schedin E, Karisson S and Steninger J 1985 Scand. J. Metallurgy 14127

Mellor P B 1981 Int. Metals Rev. 261

Mishra Sanak and Darmann C 1982 Int. Metals Rev. 27307

Miyaji $\mathrm{H}$ and Watanabe S 1980 Trans. Natl. Res. Inst. Metals 22131

Morrison W B 1966 Trans. ASM 50824

Paul S K and Mishra Sanak 1988 Steel India 1167

Paul S K and Mishra Sanak 1992 Metals Mater.\& Process. 4189

Paul S K, Mishra Sanak and Ramaswamy V 1982a Steel India 571

Paul S K. Chakrabarty A K and Basu S 1982b Metall. Trans. B13 185

Paul S K, Singh R K P. Nandi R K and Mishra Sanak 1985 Trans. IIM 38314

Paul S K, Mishra Sanak, De A K and Sodhi M M S 1989 SE AISI Quarterly 62

Paul S K, Kumar S, Mishra Sanak and Ramaswamy V 1992 Trans. IIM 45163

Paul S K, Sodhi M M S, De A K and Singh Y 1993 Steel India 1691

Pearce R 1971 Sheet Met. Ind. 48943

Pickering F B 1976 Int. Metals Rev. 211

Reis F, Dickinson D W and Franklin J E 1982 Iron and Steel Maker 28

Schedin E, Hedman M and Melander A 1982 Swedish Inst. Metals Res., Stockholm. Tech. Rep IM 1864

Vieth R W and Whiteley R L 1964 IDDRG Colloq. (London: Institute of Sheet Metal Engineering)

Waudby P E 1978 Int. Metals Rev. 2374

Whiteley R L, Wise D E and Blickwede D J 1961 Sheet Met. Ind. 38349 